\title{
Article \\ Characteristics of the Main- and Side-Stream Products of Microwave Assisted Torrefaction of Lignocellulosic Biomass of Different Origination
}

\author{
Alexandr Arshanitsa ${ }^{1,2, *}$, Lilija Jashina ${ }^{1}$, Matiss Pals ${ }^{1}{ }^{1}$, Jevgenija Ponomarenko ${ }^{1,2}$, Yegor Akishin ${ }^{2}$ \\ and Maja Zake ${ }^{3}$ \\ 1 Latvian State Institute of Wood Chemistry, Dzerbenes 27, LV-1006 Riga, Latvia \\ lilija_jasina@inbox.lv (L.J.); matiss.pals@kki.lv (M.P.); jevgenijaponomarenko@inbox.lv (J.P.) \\ 2 Ekokompozit Ltd., Dzerbenes 27, LV-1006 Riga, Latvia; akishinyegor@inbox.lv \\ 3 Institute of Physics, University of Latvia, Miera 32, LV-2169 Salaspils, Latvia; maija.zake@lu.lv \\ * Correspondence: arshanica@edi.lv; Tel.: +371-294-729-42
}

check for

updates

Citation: Arshanitsa, A.; Jashina, L.; Pals, M.; Ponomarenko, J.; Akishin, Y.; Zake, M. Characteristics of the Main- and Side-Stream Products of Microwave Assisted Torrefaction of Lignocellulosic Biomass of Differen Origination. Energies 2022, 15, 1857. https://doi.org/10.3390/en15051857 Academic Editors: Alberto-Jesus Perea-Moreno and Dimitrios Sidiras

Received: 1 February 2022

Accepted: 2 March 2022

Published: 2 March 2022

Publisher's Note: MDPI stays neutral with regard to jurisdictional claims in published maps and institutional affiliations.

Copyright: (c) 2022 by the authors. Licensee MDPI, Basel, Switzerland. This article is an open access article distributed under the terms and conditions of the Creative Commons Attribution (CC BY) license (https:// creativecommons.org/licenses/by/ $4.0 /)$.

\begin{abstract}
In this paper, the yields and composition of solid and condensable products that were obtained by microwave-assisted torrefaction of softwood, wheat straw, and peat fuel pellets, defined as main- and side-stream torrefaction products, were studied. The torrefaction process, at temperatures varied in the range of $200-300{ }^{\circ} \mathrm{C}$, was performed using a laboratory-scale torrefactor of original construction. Water-enriched fractions were distilled off from condensable products to isolate tar fractions, the fuel characteristics of which were compared with those of solid fractions. Py-GC/MS/FID, GC/MS/FID, thermal analysis, elemental analysis, and wet chemistry methods were used to characterize the main- and side-stream torrefaction products, with a focus on their valorization according to the biorefinery approach. The simultaneous development of the destruction and condensation processes in lignocarbohydrate complexes during microwave treatment leads to an increase in the relative portion of aromatic compounds in torrefied biomass, increasing the higher heating value (HHV) of the solid fractions. The increase up to $60 \%$ of the heat amount that was liberated due to the thermal oxidative conversion of solid fractions vs. that of the non-treated ones was established by DSC tests. The heat that was liberated by the combustion of the tar fractions was much lower than that of solid fractions, which was explained by the composition of tars, influencing their thermal conversion.
\end{abstract}

Keywords: lignocellulosic; microwave; torrefaction; solid fraction; tar fraction; analytical pyrolysis; combustion; thermal analysis

\section{Introduction}

The European strategic long-term vision for the modern, competitive, and climate neutral economy is executed in accordance with the Paris Agreement, reaching net-zero GHG emissions as early as possible and by 2050 at the latest [1]. The propriety of this long-term strategy was also supported by the decisions of the 26th United Nations Climate Change Conference (COP26), which was held in Glasgow. It was declared that the final agreement was aimed at keeping alive the overarching goal of limiting warming to $1.5^{\circ} \mathrm{C}$ since pre-industrial times, taking into account the fact that the world has already warmed by $1.1^{\circ} \mathrm{C}$ [2]. Therefore, reducing the dependence of the human community on fossil fuels by its gradual substitution with renewable sources, including hydropower, solar, wind, biomass, etc., is the challenge of the modern bio-economy. Among other fossilbased energy resources, coal is the single biggest contributor to anthropogenic climate change. Its contribution to climate change accounts for $40 \%$ of the global $\mathrm{CO}_{2}$ emissions from energy use and about $72 \%$ of the total greenhouse gas (GHG) emissions from the electricity sector [3]. According to the Glasgow summit decisions, 750 coal-fired power 
plants (550 GW) around the world have a phase-out date, and 90 new coal power projects $(88 \mathrm{GW})$ are likely to be cancelled [4]. The novel economic and environmental factors require more intensive substitution of fossil coal by renewable fuel.

In fact, plant biomass can be considered as a sustainable solid fuel to replace more or less complete fossil coal, the consumption of which in 2019 in EU was 596 million $t$ for heat and electricity production [2]. Almost half of the energy use in the end sector is in the form of heat. Today, about $87 \%$ of the biomass heat that is generated globally is in Europe. Direct combustion of solid fuel represents a major segment of modern energy technology, finding application for industrial and domestic heating. In 2016, 86\% of the biomass that was utilized for energy purposes was primary solid biofuels, including chips, wood pellets, and fuelwood [5].

The direct substitution of coal is restricted by some inherent properties of plant raw biomass, namely, low bulk density, high hydrophobicity, and low calorific values, compared to the case of coal. These limitations influence the logistics and storage of biomass as well as the final energy efficiency and render the application of raw biomass on a large scale.

Densification by means of pelletizing is considered to be a proven technology to improve the biomass properties to convert it into heat and energy, increasing the bulk density of pellets and, therefore, decreasing the logistic consumption.

The total wood pellet consumption in the EU reached 30.8 million $t$ in 2020 against 29.1 million metric tons in 2021 [6]. According to the report, the EU currently produces approximately $30 \%$ of the world's pellet production, but accounts for $50 \%$ of the global consumption [6]. About $66 \%$ of pellets that were consumed in Europe were used for residential $(<50 \mathrm{~kW})$ heating, and the others were used for commercial and $\mathrm{CHP}$ heating plants. However, pelletizing does not influence the calorific values of biomass, which, as a rule, does not exceed $20 \mathrm{MJ} / \mathrm{kg}$ (as a higher heating value) on the dry matter of the material. In this term, the thermal conversion of lignocellulosic biomass in conditions of mild pyrolysis, so-called torrefaction, which is performed in the range of $200-300{ }^{\circ} \mathrm{C}$ in air-free media, is a promising technology to recover the energy of biomass and to improve the fuel characteristics of solid fractions, making them similar to coal [7-9]. As a result of torrefaction, water and part of the high oxygen-containing compounds are removed from the biomass, which results in a solid residue with a higher calorific value and hydrophobicity in comparison with the starting biomass. Moreover, the technico-economic evaluation testified that the efficiency of torrefaction is up to $94 \%$ in comparison with $84 \%$ and $64 \%$ for pelletizing and pyrolysis, respectively [10].

Due to these facts, torrefied biomass has a big potential of commercial application in such fields where coal is currently used, including the heating sector, power (co-firing), gasification, and steel production (as reducing) $[9,10]$. In Europe, adapted biomass fuels for co-firing in coal power stations, with relatively minor technical adaptations and at an acceptable cost, could significantly support the fulfillment of the political targets concerning the drop of greenhouse emissions $[9,10]$. This requires bioenergy carriers that behave similarly to coal during logistics, milling, combustion, and gasification in order to use the existing infrastructure. At the same time, the demand for torrefied biomass for a large power producer only in Europe is estimated as 70 million $t$ annually. Besides, beyond the energy application of torrefied biomass, its application as a biochar, which can support the plant growth and promote the carbon availability by soils, has big potential [11].

It was shown that the global greenhouse emissions (GH) per GJ of heat in the case of torrefied pellets were lower by $30-50 \%$ in comparison with those of conventional pellets [12]. The net benefit that was expressed in USD/GJ, taking into account the cost of the raw material, and the charge for production and shipping was higher by $30 \%$ in the case of the application of torrefied pellets in comparison with conventional pellets [13].

The torrefaction process is under active development all over the world, and different technological schemes of processing are under testing. Therefore, the search for innovative heating methods that are able to decrease the energy consumption for processing and improve the yield and quality of the product is an urgent task. One of these approaches-the use of 
microwave (MW) irradiation at the frequency of $2.45 \mathrm{GHz}$-is an alternative source of energy instead of conventional heating at thermal conversion of lignocellulosic biomass [14-19].

The main advantage of MW-assisted heating includes the selective volumetric heating of lignocellulosic biomass by means of the dipolar polarization mechanism due to a significant content of polar $\mathrm{OH}$ groups in them, that allows the fast heating of biomass with a low thermal conductivity and a high heat capacity, which varied for wood pellets in the ranges of $0.146-0.192 \mathrm{~W} /(\mathrm{mK})$ and $1.074-1.253 \mathrm{~kJ} /(\mathrm{kgK})$, respectively [20]. Moreover, the ability to start and stop heating immediately improves the process control [13]. It is important that, at the microwave treatment of biomass, the temperature gradient and concentration gradient of the removed products work in the same directions from the inside to outside of the particle. At the conventional heating level, the temperature and concentration gradients work in opposite directions. As a result, it can be assumed that there are differences in the final yields and composition of the pyrolysis products under both heating systems due to the specific MW effect $[14,21]$. In the present work, the compositions of solid char fractions and tar fractions, defined, correspondingly, as main- and side-stream products of torrefaction of three types of lignocellulosic biomass, mainly softwood, wheat straw, and peat in the form of commercial pellets, were studied. The effect of MW-assisted pre-treatment on the transformation of the lignocarbohydrate complex of biomass of different origination and possible valorization of both fractions, including energy and beyond energy application of tar fractions, was discussed.

\section{Materials and Methods}

\subsection{Materials}

Commercial softwood pellets with a diameter of $6.0 \mathrm{~mm}$, wheat straw, and peat pellets, both with a diameter of $8.0 \mathrm{~mm}$ and water contents of $7.0 \%, 10.2 \%$, and $8.9 \%$, respectively, were used as an object of investigation.

\subsection{MW Assisted Torrefaction of Pellets}

An MW laboratory device of original construction was equipped with a magnetron (MW power $0.850 \mathrm{~kW}$ at $2.45 \mathrm{GHz}$ ), a coaxial wave guide, a rotated Si glass reactor $(\mathrm{V}=1.35 \mathrm{~L})$ that was placed in a tubular resonator $(\mathrm{V}=40 \mathrm{~L})$, a condenser tool for the collection of the condensable fraction, and an ejector for removal of the gaseous products was used. A thermocouple controller and a Power indicator SENECA S604E-6-MOD were applied for processing. The pellets ( $300 \mathrm{~g}$ ) were heated by microwave in argon atmosphere in the rotated reactor that was placed in the resonator up to the maximal temperature, which was $200^{\circ} \mathrm{C}, 250^{\circ} \mathrm{C}$, and $300^{\circ} \mathrm{C}$, respectively, for each sample at constant MW power, followed by isothermal heating during $20 \mathrm{~min}$ (on/off regime of the magnetron action). A detailed description of the mentioned device and the regimes of the pellets' treatment was presented elsewhere [15]. The yields of the solid and condensable fractions were measured by weighing. The yield of the non-condensable gases was calculated by the difference between the weight of pellets and the sum weight of the condensable and solid fractions. A total of five repetitions were performed for each temperature and biomass origin, and the averaged data of the products' yields were calculated. The combined fractions of the solid and condensable products of repeated experiments were used for analysis. The char was crushed in a knife type mill Retch 100 with a sieve size of $0.5 \mathrm{~mm}$. About $5 \mathrm{~g}$ of products, that were randomly chosen from each batch, were ground additionally in a Mixer Ball Mill MM 200, oven dried at $105^{\circ} \mathrm{C}$, and then used for analysis.

\subsection{Fractionation of Condensable Products}

A schematic diagram of the whole process of the study in this paper is presented below (Figure 1). 


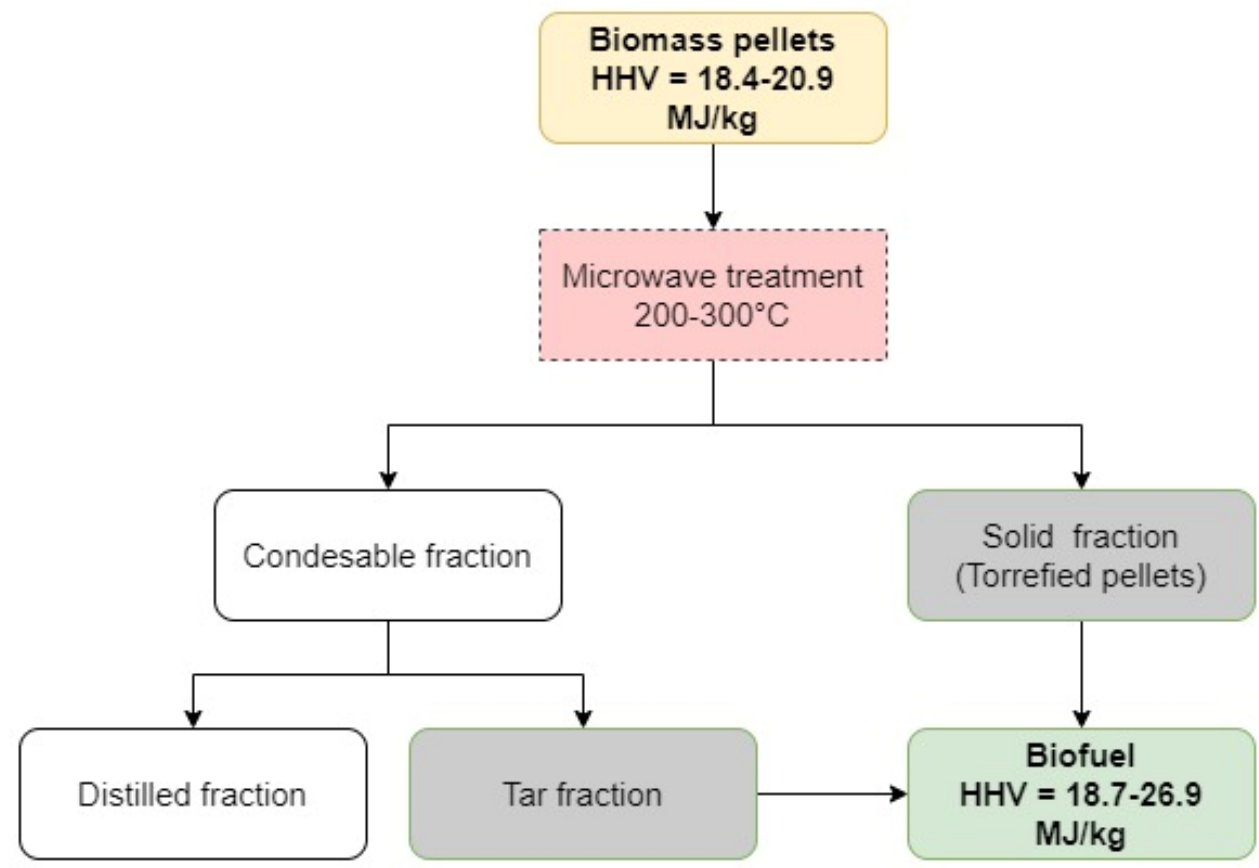

Figure 1. Schematic diagram of the performed experiments.

The tar that was contained in the condensable products was separated by distillation of the water-enriched fraction from condensates at a temperature of $80{ }^{\circ} \mathrm{C}$ and a residual pressure of 90-100 mbar, using a rotation evaporator (Heidohoph Hei-VAP precision). The vacuum thermal treatment of tar was prolonged during $1 \mathrm{~h}$ from the moment of the visible termination of distillation. The yield of tar in the condensate was determined by weighing the fraction remaining after distillation.

\subsection{Analytical Pyrolysis (Py-GC/MS/FID)}

To estimate the transformation of lignocellulosic components at MW-assisted torrefaction pyrolysis, gas chromatography-mass spectrometry (Py-GC/MS/FID) of the non-treated biomass, solid, and tar fractions was performed using a Frontier (Denver, $\mathrm{CO}$, USA) Lab Micro-shot Pyrolizer Py-2020iD (temperature of pyrolysis $773 \mathrm{~K}$, heating rate $600 \mathrm{~K} \mathrm{~s}^{-1}$ ), that was directly coupled with a Shimadzu (Kyoto, Japan) GC/MS-QP 2010 apparatus, with a capillary column RTX-1701 (injector temperature, $250{ }^{\circ} \mathrm{C}$, MS scan range $\mathrm{m} / \mathrm{z} 15-350$, carrier gas helium). The mass of a sample was $1.00-1.10 \mathrm{mg}$. The oven program was $1 \mathrm{~min}$ of isothermal at $333 \mathrm{~K}$, then heating at a rate of $6 \mathrm{~K} \mathrm{~min}^{-1}$ to $543 \mathrm{~K}$ and $10 \mathrm{~min}$ storage. The identification of the individual compounds was performed on the basis of GC/MS data using the Library MS NIST 147.L113, whereas the relative area of the peaks of the individual compounds was calculated by using Shimadzu software on the basis of GC/FID data. A total of three repeated tests were done, and the averaged data were used for discussion, with the variation coefficient $(\mathrm{CV})$ for the relative area of the individual components determination within the range of $5.0-6.5 \%$.

\subsection{GC/MS/FID}

The water-enriched fraction distilled from the condensable products was solubilized in acetone ( $<99 \%$, GC quality) 1:1 by volume. A total of three aliquots with a volume of $2.00 \mathrm{~mL}$ per each were randomly chosen for each batch of the distillate.

A total of three samples of each tar fraction with the weight of $0.5000 \pm 0.0010 \mathrm{~g}$ per each were solubilized in acetone $(1: 5 w / w)$ and filtered $(0.45 \mu \mathrm{m}$ nylon syringe filters). A total of $2 \mu \mathrm{L}$ of each prepared solution was directly injected into the Shimadzu injector of the GC/MS QP 2010 apparatus. The identification of the individual components and calculation of their relative content in distillates and tar fractions were performed as 
described above. The $\mathrm{CV}$ of the relative area of the organic components' determination was $\leq 8.0 \%$

\subsection{Potentiometric Titration}

The total content of carbonic acid (mol/L) in the distillates was determined by potentiometric titration of $5.0-6.0 \mathrm{~mL}$ aliquot with $0.1 \mathrm{M} \mathrm{NaOH}$ using an automatic titration manager TIM 840. The molar concentration of the carbonic acids was recalculated on the weight concentration $(\mathrm{g} / \mathrm{L})$, assuming that only acetic acid was presented in the distillate. From three to five repetitions were done with CV within 3.5-5.0\%.

\subsection{TG/DTG/DSC Analysis}

Non-isothermal TG/DTG/DSC analysis of the non-treated biomass, torrefied solid, and tar fractions was performed using a Setaram (Lyon, France) Setline device in air media. The sample weight was $10 \mathrm{mg}$, range $25-650{ }^{\circ} \mathrm{C}$, heating rate $10^{\circ} \mathrm{C} / \mathrm{min}$. The tar fractions that were obtained by $\mathrm{MW}$-assisted torrefaction of the biomass at $300{ }^{\circ} \mathrm{C}$ were also tested in inert (Ar) media. The liberated heat amount was calculated using Seteram Setline Calisto software.

A total of three repeated experiments were performed for each sample.

\subsection{Elemental Analysis}

Elemental analysis $(\mathrm{C}, \mathrm{H}, \mathrm{N})$ of the non-treated biomass, char, and tar fractions was measured using a Vario MACRO elemental analyzer (ELEMENTAR Analysensysteme). The sample weight for the five repeated experiments varied in the range of 50-75 mg.

\subsection{Higher Heating Value (HHV)}

The higher heating values of the non-treated biomass, char, and tar products were calculated by regression (1) [15]:

$$
\mathrm{HHV}=\left(3.55^{2}-232 \mathrm{C}-2230 \mathrm{H}+51.2 \mathrm{C} \times \mathrm{H}+131 \mathrm{~N}+20,600\right) / 1000
$$

where $\mathrm{C}, \mathrm{H}$, and $\mathrm{N}$ is the carbon, hydrogen, and nitrogen content, respectively, in percent on the dry basis of biomass.

\subsection{Ash Content}

The ash content in the non-treated biomass and solid fractions was measured in triplicate for each sample as a residue after ignition at $550 \pm 10{ }^{\circ} \mathrm{C}$ according to the LVS EN 14775: 2010 Standard. The ash content in the tar fraction was estimated as the residual weight after its TG/DTG/DSC analysis in air media.

\section{Results}

\subsection{Yield of Products of MW Assisted Torrefaction of Plant Biomass of Different Origination}

The mass balance of the fractions that were obtained as a result of MW-assisted torrefaction, coupled with the data of the water content in the starting biomass, testified that drying was the dominant but not the single process of biomass transformation by MWassisted processing at $200{ }^{\circ} \mathrm{C}$. For softwood and wheat straw, the off-gases of torrefaction, including condensable and non-condensable products, consisted of about $80 \%$ physically bonded water. For peat, this value was $64 \%$.

This means that the measurable thermal degradation/transformation of the biomass complex, accompanied by chemically-bonded water and organic emission, starts at a low temperature $\left(20{ }^{\circ} \mathrm{C}\right)$ of $\mathrm{MW}$-assisted treatment, significantly increasing with growing torrefaction temperature. With increasing temperature of MW processing, the yield of both the condensable and non-condensable fractions increased for all types of biomass (Figure 2). The calculated portion of the physically-bonded water in off-gases of torrefaction significantly decreased and was $18.8 \%, 17.6 \%$, and $22.9 \%$ for softwood, wheat straw, and 
peat, respectively, that were all torrefied at $300^{\circ} \mathrm{C}$. As was shown, the wheat straw revealed itself as the most thermolabile substrate. After MW-assisted torrefaction at $300{ }^{\circ} \mathrm{C}$, only $42.1 \%$ of the initial biomass remained as a solid fraction, followed by peat $(61.2 \%)$ and softwood $(62.1 \%)$, both torrefied at $300{ }^{\circ} \mathrm{C}$. The yields of the condensable fractions at this temperature varied in the range of $25.8-41.9 \%$ of the received weight of the initial material. Therefore, the comprehensive characterization of not only the solid fraction, defined as the main-stream product of torrefaction, but also these side-stream products, meets the requirements of the biorefinery principle with the final target of these products' valorization, allowing to decrease the prime cost of the main-stream product and to eliminate the environmental impact.

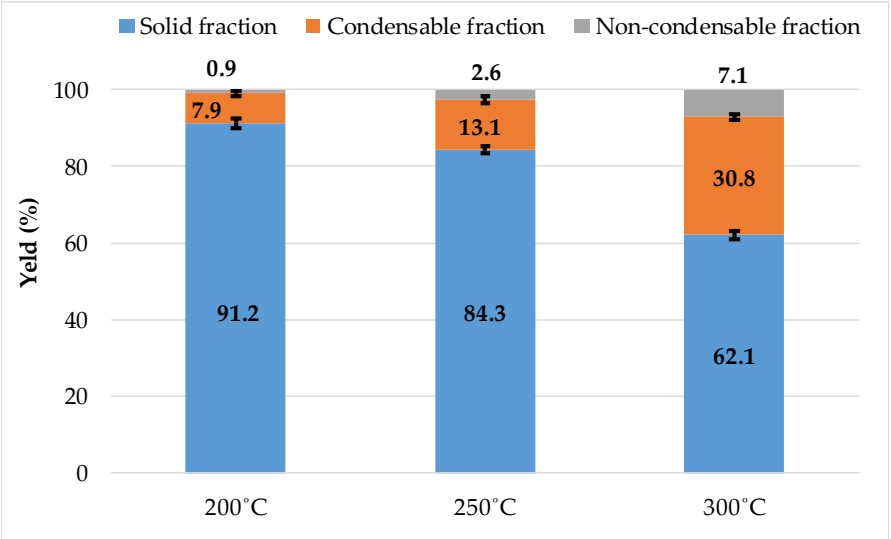

(a)

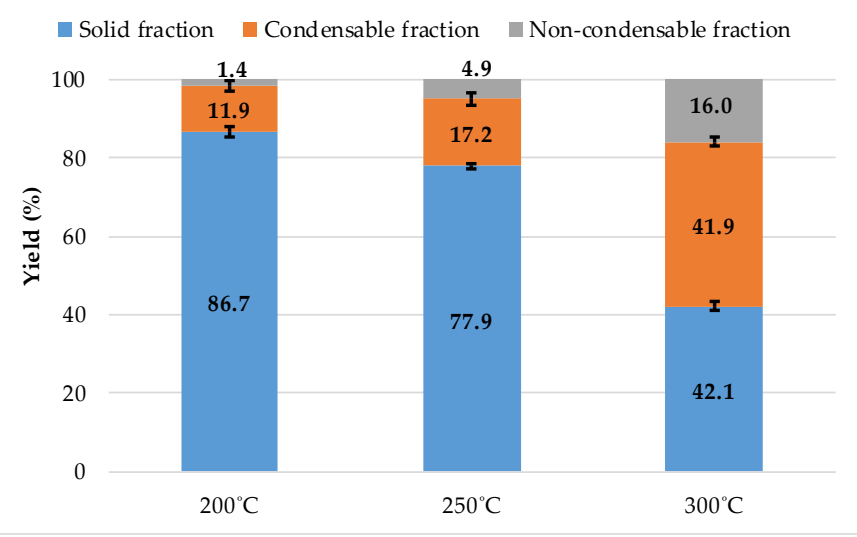

(b)

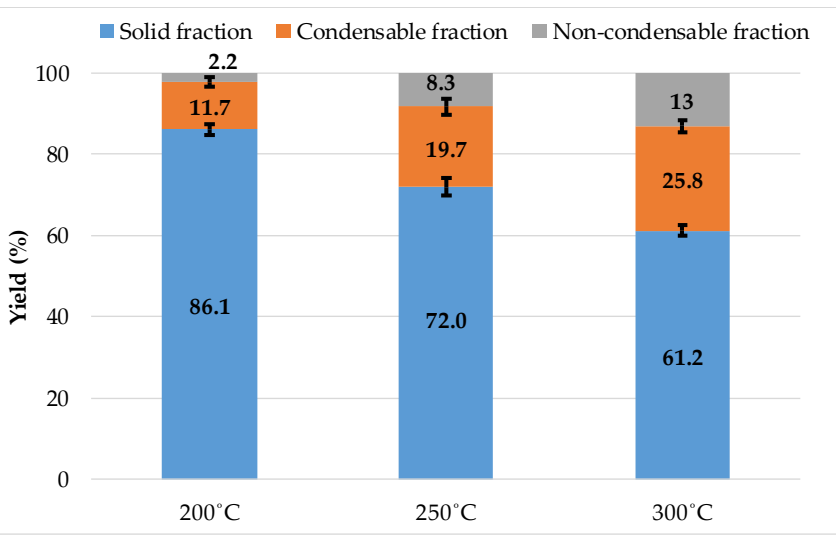

(c)

Figure 2. Yields of the products of MW-assisted torrefaction of biomass of different origination: (a) softwood, (b) wheat straw, and (c) peat.

\subsection{Separation of Tar from Condensable Fractions and Characteristics of Water Enriched Distillates}

The yield of condensable fractions of MW-assisted torrefaction of softwood, wheat straw, and peat varied in the ranges of $7.9-30.8 \%, 11.9-41.9 \%$, and $11.7-25.8 \%$, respectively, increasing with the growth of the torrefaction temperature (Figure 2). The obtained fractions represent an emulsion, containing the removed chemically- and physically-bonded water, water soluble organic, and more complicated water insoluble products of the biomass thermal transformation, that were formed as a result of different processes, including evaporation, condensation, and the degradation of the lignocarbohydrate complex.

It has been shown that water is the main component of all condensable fractions, resulting in the drying of biomass, dehydration of cellulose, and condensation reactions of lignin, therefore, decreasing the $\mathrm{O} / \mathrm{C}$ and $\mathrm{H} / \mathrm{C}$ ratios in the remaining biomass [22]. The content of the tar fraction was negligible in the condensates that were obtained at $200{ }^{\circ} \mathrm{C}$, 
steadily increasing with the growth in the temperature of MW-assisted treatment, which promoted the formation of volatiles, containing comparatively high molecular fragments of thermal degradation of the major biomass components. The highest yield of tar, equal to $28.6 \%$ of the weight of the condensable fraction or $13.3 \%$ of the dry weight of the biomass, was determined for the condensable torrefaction products of wheat straw, that were obtained at $300{ }^{\circ} \mathrm{C}$. At the same torrefaction temperature, the lowest yield of tar was measured for softwood, followed by peat, namely, $7.3 \%$ and $13.4 \%$, respectively (Figure 3 ). The compositions of water solutions that were distilled from the condensable fractions are presented in Table 1.

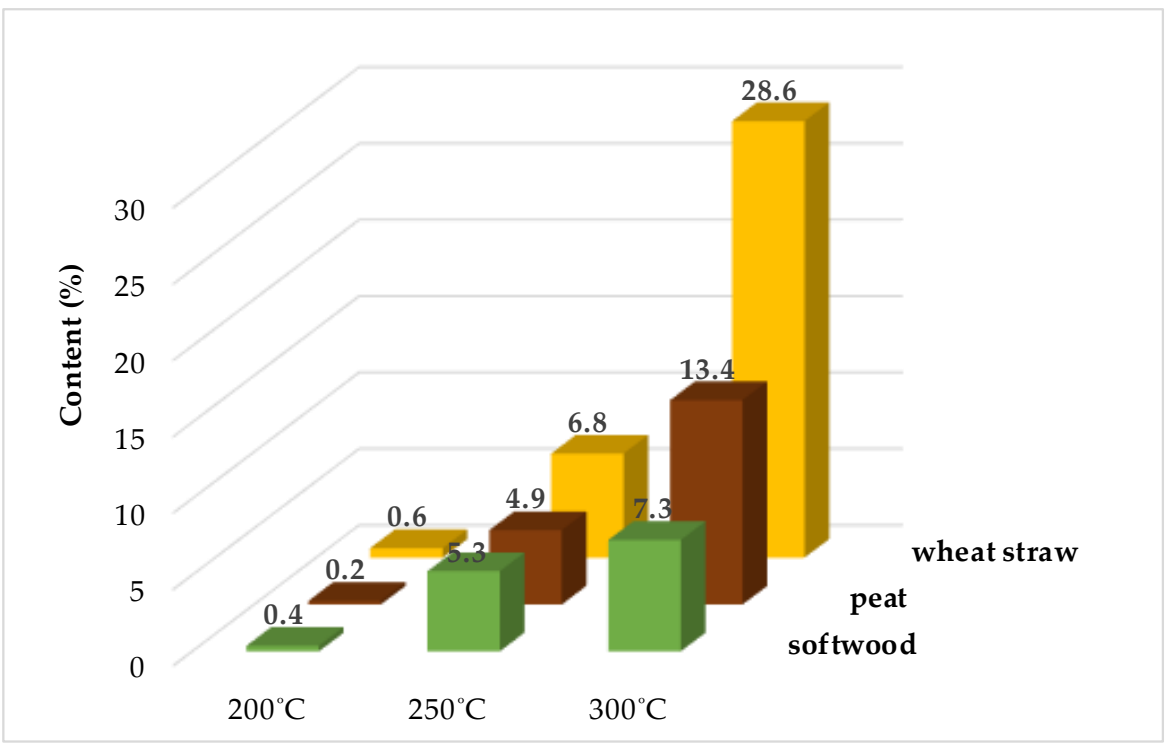

Figure 3. Yields of tar that were isolated from the condensable fractions that were obtained by MW-assisted torrefaction of different types of lignocellulosic biomass.

Table 1. Content and composition of the organic substituents that were present in the water distillates that were removed from the condensable products of $\mathrm{MW}$-assisted torrefaction of biomass, that were obtained at different temperatures according to the GC data.

\begin{tabular}{|c|c|c|c|c|c|c|c|c|c|}
\hline \multirow{2}{*}{ Index } & \multicolumn{3}{|c|}{ Softwood } & \multicolumn{3}{|c|}{ Wheat Straw } & \multicolumn{3}{|c|}{ Peat } \\
\hline & $200{ }^{\circ} \mathrm{C}$ & $250{ }^{\circ} \mathrm{C}$ & $300^{\circ} \mathrm{C}$ & $200{ }^{\circ} \mathrm{C}$ & $250^{\circ} \mathrm{C}$ & $300{ }^{\circ} \mathrm{C}$ & $200{ }^{\circ} \mathrm{C}$ & $250^{\circ} \mathrm{C}$ & $300{ }^{\circ} \mathrm{C}$ \\
\hline Total area, (AU) & 0.81 & 3.95 & 7.23 & 3.58 & 10.68 & 15.32 & 0.89 & 5.61 & 5.37 \\
\hline \multicolumn{10}{|l|}{$\begin{array}{c}\text { Total carboxylic } \\
\text { acids: }\end{array}$} \\
\hline Area (AU) & 0.74 & 3.36 & 4.94 & 3.41 & 9.00 & 11.7 & 0.31 & 2.12 & 1.62 \\
\hline Content $(\%)^{*}$ & 91.4 & 85.1 & 68.7 & 95.3 & 84.3 & 76.4 & 34.9 & 37.8 & 30.1 \\
\hline \multicolumn{10}{|l|}{ Acetic acid } \\
\hline Area (AU) & 0.46 & 2.63 & 4.43 & 3.03 & 7.02 & 8.26 & 0.29 & 1.86 & 1.33 \\
\hline Content $(\%) *$ & 56.8 & 66.6 & 61.3 & 84.6 & 65.7 & 53.9 & 32.1 & 33.2 & 24.8 \\
\hline \multicolumn{10}{|l|}{$\begin{array}{c}\text { Furfural and } \\
\text { 5-methyl furfural: } \\
\text { Area (AU) }\end{array}$} \\
\hline \multirow[t]{2}{*}{ Content $(\%)^{*}$} & 0.06 & 0.30 & 0.68 & 0.02 & 0.17 & 0.49 & 0.58 & 3.14 & 3.11 \\
\hline & 7.40 & 7.60 & 9.40 & 0.56 & 1.60 & 3.20 & 65.1 & 56.0 & 57.9 \\
\hline \multicolumn{10}{|l|}{ Other organics: } \\
\hline Area (AU) & 0.02 & 0.29 & 1.58 & 0.16 & 1.51 & 3.09 & - & 0.35 & 0.64 \\
\hline Content (\%) & 2.47 & 7.30 & 21.9 & 4.47 & 14.10 & 20.2 & - & 6.22 & 12.0 \\
\hline
\end{tabular}

* in percent on the total area of the organic chromatogram. 
According to the GC data, the total content of the organic compounds that were estimated as the total area of chromatographic peaks that were detected in the waterenriched distillates steadily increased with increasing torrefaction temperature. At a given temperature, the total content of organic admixtures that were detected in the distillates that were removed from condensable products of wheat straw torrefaction, exceeded that which was detected in the distillates of softwood and peat 2.0-4.5 times, indicating the highest degradation ability of wheat straw during the MW treatment.

For the distillate fractions that were isolated from the condensable products of softwood and wheat straw that were removed as a result of the MW treatment, monofunctional organic acids, such as acetic, formic, and butanoic acids, accounted for $69-95 \%$ of the total organic content, with a dominant portion of acetic acid (Table 1). It is known that deacetylation of both hemicellulose and acetylated oligosaccharides as a result of the hydro-thermal treatment of biomass leads to the formation of acetic acid. This process starts at $145^{\circ} \mathrm{C}$ [23]. The concentration of acetic acid in the distillates of wheat straw was the highest due to the higher content of acetyl groups in the wheat straw hemicelluloses in comparison with that of softwood. For example, the content of acetyl groups in the wheat straw lignocellulose was estimated as $2.2 \%$ on the dry weight vs. $1.2 \%$ for pine wood [24]. The acetic acid content in the distillates that were obtained from condensable products of the MW-assisted torrefaction of peat was up to six and four times lower in comparison with that of the wheat straw and softwood distillates, respectively. In this case, hydrolysis of the acetyl groups in terrestrial plant hemicelluloses took place partly during the long term decomposition of biomass in conditions of high humidity [25]. The GC data are confirmed by the data of potentiometric titration of distillates. The total content of organic acids are expressed as the content of the dominant acetic acid $(\mathrm{g} / \mathrm{L})$ is presented in Figure 4.

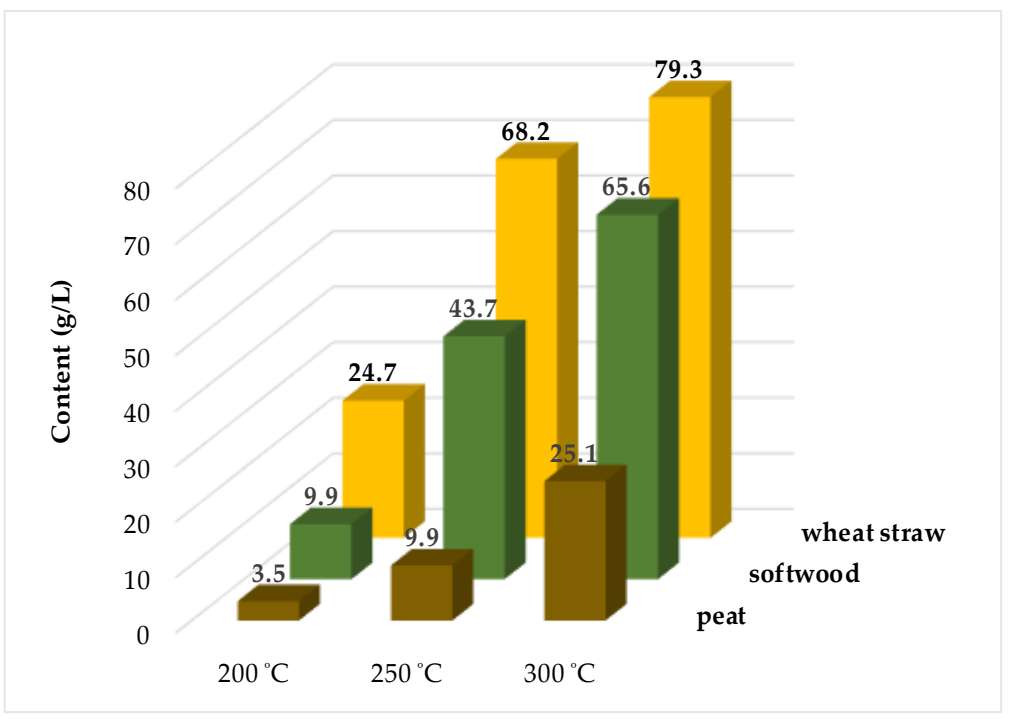

Figure 4. Total content of organic acids in the distillates that were recalculated on the acetic acid content.

The concentration of acids in the different distillates was increased in the range: peat $<$ softwood $<$ wheat straw.

In contrast to the composition of the distillates that were isolated from the condensable fractions of softwood and wheat straw, 2-furfuralal aldehyde (furfural) and 5-hydroxymethyl-2-furfuraldehyde (5-methyl furfural) were the dominant components (56-65.1\%) in the distillates of the condensable fractions of peat, but the portion of these compounds in the fractions that were distilled from the condensates of wood and wheat straw torrefaction was much lower, i.e., $6.9-9.40 \%$, and $0.5-3.2 \%$, respectively. Furfural and 5-methyl furfural are readily produced at an enhanced temperature as a result of the acid catalyzed dehydration of monomeric pentoses and hexoses, respectively [26]. Obviously, the content of the monomeric carbohydrates that were present in peat was much 
higher than that in the cell wall of native lignocelluloses due to the depolymerization and hydrolysis of carbohydrates, performed in the long-term period of peat formation.

The concentration of "other organics" in distillates steadily increased with increasing torrefaction temperature for all types of biomass. The maximal concentration of the "other organics" in the distillates was determined in the case of wheat straw, followed by softwood and peat (Table 1). This group of compounds included predominantly 1-hydroxy-2 butanone, guaiacol derivatives, phenols, and esters of propionic acid.

It has been shown that the water fractions that were removed from the condensable products of the $\mathrm{MW}$-assisted treatment of lignocellulosic biomass to separate tar are enriched with different organic compounds. The yield of distillates, depending on the torrefaction temperature, is varied in the range of $8-29 \%, 12-30 \%$, and $12-22 \%$ on the weight of the starting biomass of softwood, wheat straw, and peat, respectively. Therefore, the negative environmental impact of distillates can be anticipated in the case of their waste interception without any purification or utilization.

\subsection{Composition of Solid and Tar Fractions Obtained by MW-Assisted Torrefaction of Different} Types of Lignocellulosic Biomass

There were two different approaches that were applied to characterize the composition of solid and tar fractions that were obtained at different regimes of MW-assisted torrefaction of lignocellulosic biomass. In the first case, the Py-GC/MS/FID method was used for breaking the macromolecules of the main components of the torrefied biomass into smaller fragments, followed by their GC detection. For tar fractions, which consisted of the volatile fragments of biomass MW-assisted degradation, the direct GC method was used. The results of Py-GC/MS/FID and GC analysis are presented in Figures 5-7.

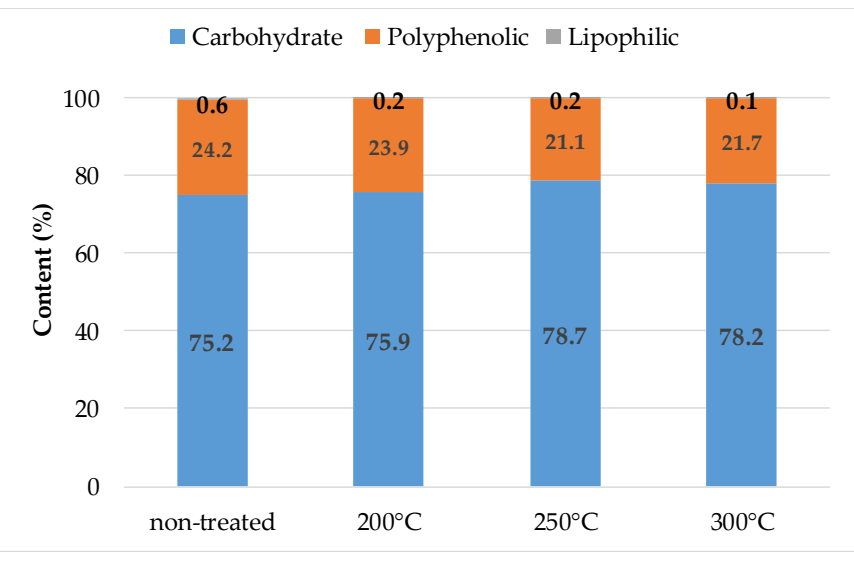

(a)

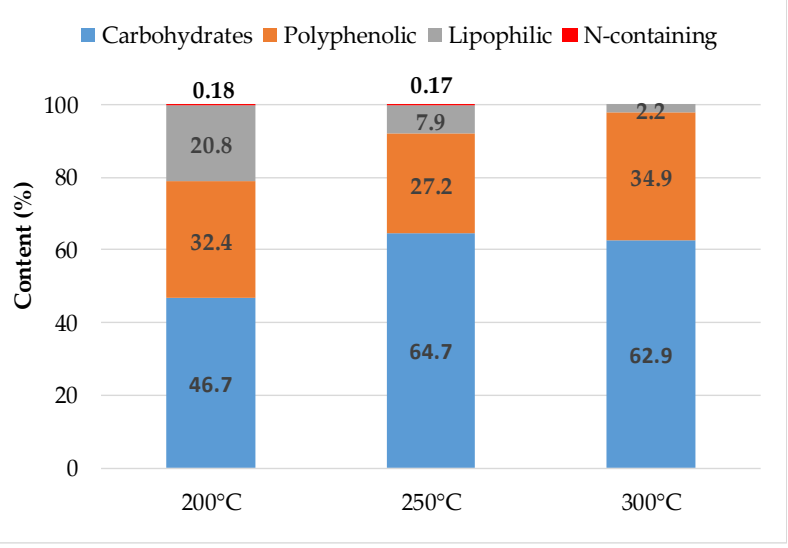

(b)

Figure 5. The relative content of carbohydrate, polyphenolic, lipophilic, and N-containing constituentderived products in pyrolysis volatiles of the non-treated and torrefied softwood solid fractions (a) and in tar fractions (b), depending on the MW treatment temperature.

As can be seen, the transformation of lignocellulosic biomass as a result of the MW treatment depends strongly on the biomass origination (Figures 5-7). The relative content of carbohydrate-derived products in Py-GC/MS volatiles of torrefied softwood was higher in comparison with that of non-treated softwood; in contrast, the relative content of the phenolic-derived compounds decreased (Figure 5). As a result, the ratio of carbohydrate-derived products to that of phenolic-derived ones for non-treated biomass was 3.1 vs. 3.6-3.7, respectively, for the biomass that were torrefied at $250-300{ }^{\circ} \mathrm{C}$. As a result of the low temperature $\left(200^{\circ} \mathrm{C}\right)$ torrefaction, this ratio increased insignificantly, i.e., up to 3.2 .

At the same time, the content of the carbohydrate-derived products in the tar fractions was 1.4-2.4-fold higher in comparison with that of phenolic-derived products. Therefore, a 
decrease in the relative content of the carbohydrate-derived compounds in solid products of torrefaction could be anticipated.

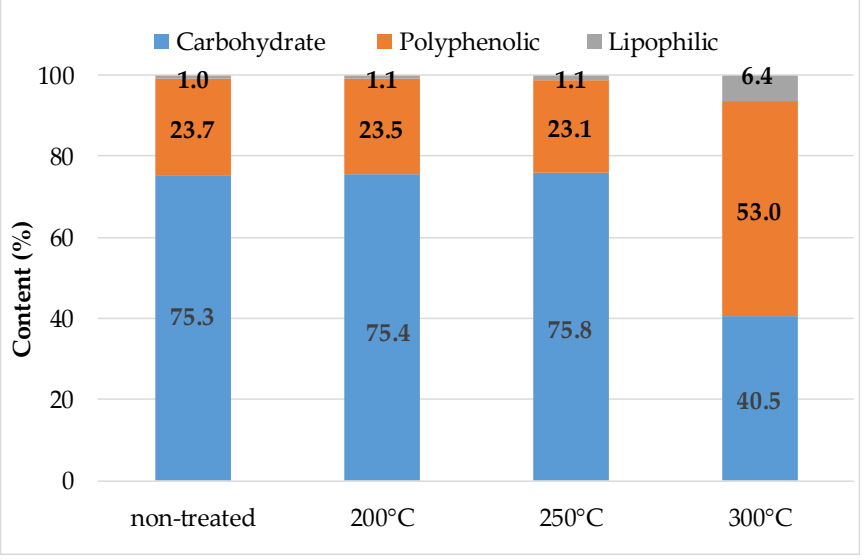

(a)

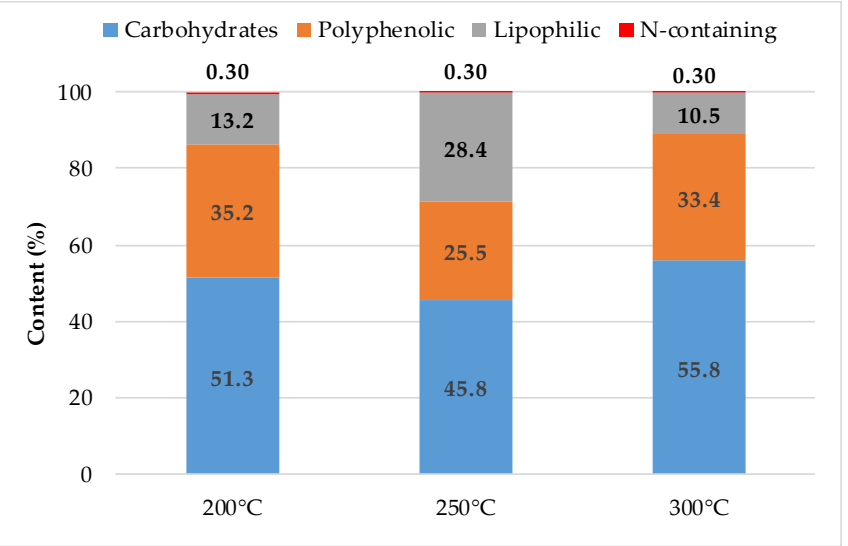

(b)

Figure 6. The relative content of carbohydrate, polyphenolic, lipophilic, and N-containing substituentderived products in pyrolysis volatiles of non-treated and torrefied wheat straw solid fractions (a), and tar fractions (b), depending on the treatment temperature.

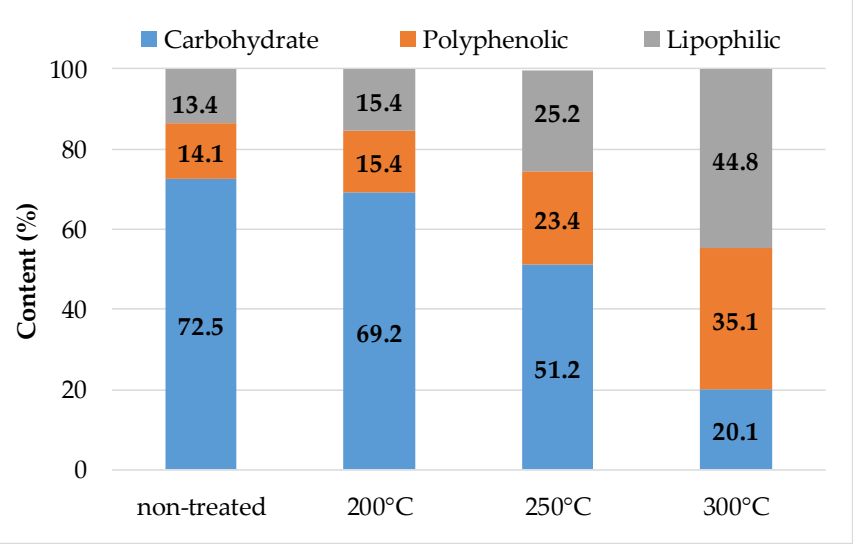

(a)

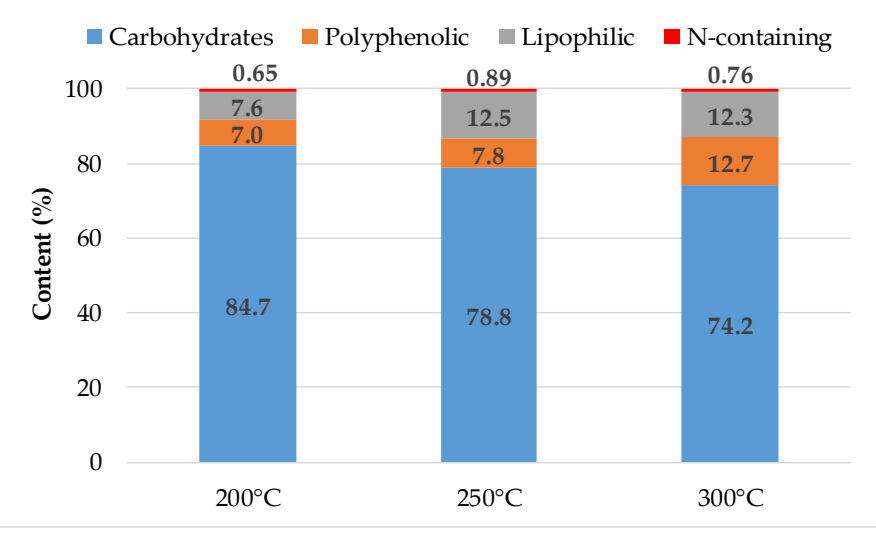

(b)

Figure 7. The relative content of carbohydrate, polyphenolic, lipophilic, and N-containing constituentderived products in pyrolysis volatiles of non-treated and torrefied peat solid fractions (a), and tar fractions (b), depending on the treatment temperature.

This contradiction has demonstrated that the process of condensation of the lignin component as a result of MW-assisted heating leads to its transformation into a thermally stable carbonized product, which is not degraded completely in the conditions of analytical pyrolysis. For example, at a similar sample weight, the total area of the chromatogram of analytical pyrolysis volatiles for softwood torrefied at $300{ }^{\circ} \mathrm{C}$ was lower by $25 \%$ in comparison with that of the non-treated wood.

In the case of the wheat straw sample that was torrefied at $200-250{ }^{\circ} \mathrm{C}$, a similar ratio of carbohydrate- to phenolic-derived volatiles, varied in the range of 3.2-3.3, was observed for treated and the non-treated biomass (Figure 6). Considering that the carbohydratederived products represent the dominant component of the wheat straw tar fraction, it can be assumed that the condensation of lignin, similarly to that which was observed for the softwood lignin, was performed as a result of the MW-assisted treatment at $200-250{ }^{\circ} \mathrm{C}$. However, for the solid fraction of the wheat straw that was torrefied at $300^{\circ} \mathrm{C}$, a drastic decrease of the carbohydrate-derived content in analytical pyrolysis volatiles was established, which was accompanied by the highest portion of carbohydrate-derived compounds in the 
tar fraction. This can be explained by the lower thermostability of wheat straw cellulose due to its amorphous structure in comparison with the ordered cellulose of softwood. These results agree with the lowest yield (42.1\%) of the solid fraction of wheat straw that was torrefied at $300{ }^{\circ} \mathrm{C}$ and the highest yield (49.1\%) of the condensable fraction (Figure $2 \mathrm{~b}$ ). As a result, according to Py-GC/MS/FID data, the high condensed lignin, which acts as a precursor of char formation, is the dominant component of the solid fraction that was obtained by the MW-assisted torrefaction of wheat straw, performed at $300^{\circ} \mathrm{C}$ (Figure 6).

Both softwood and wheat straw are characterized by an unaltered cell structure and a native molecular and supra molecular structure of the major cell wall components, including lignin and cellulose. However, peat is formed from plant biomass as a result of three possible types of degradation reaction, i.e., abiotic, biotic, and pyrolytic degradation of organic material. The presence of amorphous humus compounds, the precursors of which are the major component of the plant cell wall, as well as the secondary metabolites and destroyed cell structure, differs this lignocellulosic from native plant biomass [27]. The Py-GC/MS/FID and GC data clearly indicate the different composition of solid and tar fractions that were obtained by the MW-assisted torrefaction of peat vs. that of the softwood and wheat straw (Figure 7).

It was shown that, in contrast to the case of softwood and wheat straw, the solid fractions that were obtained by the torrefaction of peat contained significant amounts of lipophilic compounds, which were detected in pyrolysis volatiles as long-chain (C10-C19) aliphatic hydrocarbons. With increasing torrefaction temperature, a continuous decrease in the content of carbohydrate-derived compounds in the pyrolysis products of the solid fractions, with a simultaneous increase in the portion of phenolic and lipophilic constituentderived products, was observed. In contrast to softwood and wheat straw biomass, the torrefaction of which led to the almost complete removal of lipophilic compounds with off-gases of torrefaction, the main portion of the lipophilic compounds was concentrated in the solid fractions of peat, which positively influenced the increment of the calorific values of the torrefied peat vs. those of the torrefied wheat straw and softwood samples. The GC analysis of the tar fractions of the biomass torrefaction has shown that they consist of low-molecular products of the degradation of phenolic compounds that are derived from lignin, phenolic extractives, humic acids, as well as products of degradation of lipophilic extractives hydrocarbons and their acids/esters, and minor N-containing compounds. The tar fractions of the torrefied biomass of pine wood and wheat straw have increased the portions of the lipophilic extractives and aromatics, in comparison to the initial biomass, while the same was not observed for peat tar (Figures 5-7). The low-molecular aliphatic aldehydes, ketones, acids, esters, and other compounds that are rich in oxygen, that were derived mostly from carbohydrates as a result of the MW treatment, dominate in the tar fractions of peat. The lipophilic compounds of wood and wheat straw tars are represented mainly by oxygen-containing compounds, including C8-C9 fatty acids, free or esterified. In the case of peat, oxygen-free hydrocarbons (paraffin) are dominant; therefore, it can be proposed that the calorific values of peat tar will be approximately the same as that of wheat straw and softwood, despite the higher content of carbohydrate-derived products in the latter.

As was shown, the monomeric phenolic compounds in an amount of $25-35 \%$ of the total content of organics were determined by GC methods in the tar fractions of softwood and wheat straw (Figures 5 and 6).

According to GC data, phenolics monomers of guaiacyl origination made up 95-98\% of the whole phenolic content in the tar fraction of softwood. In the tar fractions of wheat straw, the sum of the methoxylated phenolic content, including guaiacyl and syringyl units, was equal to $91-99 \%$ of the total phenolic content. This means that the degradation/depolymerization of lignin, which is the precursor of methoxylated phenolic monomers, proceeds actively as a result of the dielectric heating of softwood and wheat straw biomass. The content of the phenolic compounds in the peat-derived tar was significantly lower and was $7-12.7 \%$ of the total organic content that can be attributed 
to the condensation of lignin during the process of peat formation, therefore, increasing their thermal stability. It is known that the depolymerization of lignin is considered to be one of the important challenges in lignin valorization [28]. The presence of ligninderived monomeric phenolic compounds in both wheat straw- and softwood-derived tar samples allow to assume a possible valorization of these products beyond energy use as antimicrobial compositions [29,30].

\subsection{Fuel Characteristics of Solid and Tar Fractions Obtained by MW-Assisted Torrefaction of Biomass of Different Origination}

In this chapter, the properties of both the solid and tar fractions are discussed in terms of their possible application as biofuel, with focus on the elemental composition, ash content, higher heating value, and behavior in combustion tests using differential scanning calorimetry and thermogravimetry.

For the softwood and peat biomass, the $\mathrm{O} / \mathrm{C}$ and $\mathrm{H} / \mathrm{C}$ atomic ratios in the obtained solid fractions steadily decreased with increasing temperature of MW treatment, testifying that carbonization of biomass takes place, which leads to an increase in the HHV of torrefied biomass, compared to the case of the starting material (Table 2). Most significantly, this process was performed in the case of wheat straw, that was MW treated at $300{ }^{\circ} \mathrm{C}$, resulting in a higher HHV value of solids in comparison with the case of softwood that was treated at the same temperature. For wheat straw, this process was accompanied by the highest $(58 \%)$ loss of solid biomass as off-gases of torrefaction among all the samples under study (Figure 2b). For peat, a similar carbon content and HHV were achieved at a higher yield of the solid fraction, resulting in lower energy losses compared to the case of wheat straw. In this case, both processes, i.e., the carbonization of biomass and the increasing of the portion of lipophilic compounds, are responsible for the increase in the carbon content and HHV of the residue.

Table 2. Comparison of the properties of solid and tar fractions that were obtained by MW-assisted torrefaction of softwood, wheat straw, and peat, performed at different temperatures in terms of $\mathrm{O} / \mathrm{C}$ and $\mathrm{H} / \mathrm{C}$ atomic ratios, $\mathrm{HHV}$, and ash content in them.

\begin{tabular}{|c|c|c|c|c|c|c|c|c|}
\hline \multirow{3}{*}{$\mathrm{T},{ }^{\circ} \mathrm{C}$} & \multicolumn{8}{|c|}{ Softwood } \\
\hline & \multicolumn{4}{|c|}{ Solid fraction } & \multicolumn{4}{|c|}{ Tar fraction } \\
\hline & $\mathrm{O} / \mathrm{C}$ & $\mathrm{H} / \mathrm{C}$ & Ash, \% & HHV, MJ/kg & $\mathrm{O} / \mathrm{C}$ & $\mathrm{H} / \mathrm{C}$ & Ash, \% & HHV, MJ/kg \\
\hline n.t * & 0.64 & 1.46 & $0.32 \pm 0.02$ & $19.9 \pm 0.2$ & - & - & - & - \\
\hline $200^{\circ} \mathrm{C}$ & 0.63 & 1.44 & $0.33 \pm 0.04$ & $20.2 \pm 0.2$ & 0.60 & 1.36 & n.d & $20.7 \pm 0.7$ \\
\hline $250^{\circ} \mathrm{C}$ & 0.56 & 1.34 & $0.36 \pm 0.05$ & $21.5 \pm 0.1$ & 0.57 & 1.20 & n.d & $21.0 \pm 0.6$ \\
\hline $300^{\circ} \mathrm{C}$ & 0.41 & 1.14 & $0.41 \pm 0.05$ & $24.5 \pm 0.3$ & 0.53 & 1.17 & n.d & $21.7 \pm 0.9$ \\
\hline \multicolumn{9}{|c|}{ Wheat straw } \\
\hline & \multicolumn{4}{|c|}{ Solid fraction } & \multicolumn{4}{|c|}{ Tar fraction } \\
\hline & $\mathrm{O} / \mathrm{C}$ & $\mathrm{H} / \mathrm{C}$ & Ash, \% & HHV, MJ/kg & $\mathrm{O} / \mathrm{C}$ & $\mathrm{H} / \mathrm{C}$ & Ash, \% & HHV, MJ/kg \\
\hline n.t ${ }^{*}$ & 0.70 & 1.50 & $3.7 \pm 0.2$ & $18.4 \pm 0.1$ & - & - & - & - \\
\hline $200^{\circ} \mathrm{C}$ & 0.65 & 1.43 & $3.9 \pm 0.3$ & $18.7 \pm 0.1$ & 0.45 & 1.21 & n.d & $23.3 \pm 0.2$ \\
\hline $250^{\circ} \mathrm{C}$ & 0.59 & 1.37 & $6.3 \pm 0.5$ & $19.6 \pm 0.2$ & 0.55 & 1.28 & n.d & $21.5 \pm 0.2$ \\
\hline $300^{\circ} \mathrm{C}$ & 0.22 & 0.90 & $10.2 \pm 1.1$ & $26.0 \pm 0.4$ & 0.45 & 1.17 & n.d & $23.9 \pm 0.6$ \\
\hline \multicolumn{9}{|c|}{ Peat } \\
\hline & \multicolumn{4}{|c|}{ Solid fraction } & \multicolumn{4}{|c|}{ Tar fraction } \\
\hline & $\mathrm{O} / \mathrm{C}$ & $\mathrm{H} / \mathrm{C}$ & Ash, \% & HHV, MJ/kg & $\mathrm{O} / \mathrm{C}$ & $\mathrm{H} / \mathrm{C}$ & Ash, \% & $\mathrm{HHV}, \mathrm{MJ} / \mathrm{kg}$ \\
\hline n.t* & 0.54 & 1.19 & $3.4 \pm 0.3$ & $20.9 \pm 0.2$ & - & - & - & \\
\hline $200^{\circ} \mathrm{C}$ & 0.47 & 1.12 & $3.6 \pm 0.4$ & $22.0 \pm 0.2$ & 0.52 & 0.75 & n.d & $21.4 \pm 0.3$ \\
\hline $250^{\circ} \mathrm{C}$ & 0.31 & 1.03 & $4.7 \pm 0.2$ & $25.4 \pm 0.4$ & 0.51 & 1.15 & n.d & $21.8 \pm 0.2$ \\
\hline $300^{\circ} \mathrm{C}$ & 0.24 & 0.88 & $5.2 \pm 0.4$ & $26.9 \pm 0.3$ & 0.43 & 1.13 & n.d & $23.7 \pm 0.2$ \\
\hline
\end{tabular}

* non-treated biomass.

The increase in the ash content as a result of the MW-assisted torrefaction, due to the concentration effect, occurred for all the samples. Therefore, the ash content in the solid 
fractions depended on both factors, including the ash content in the starting biomass and the weight loss during the torrefaction. For example, the ash content in the wheat straw torrefied at $300{ }^{\circ} \mathrm{C}$ was two-fold higher in comparison with the case of the peat that was torrefied at the same temperature, despite the similar ash content in the starting biomass (Table 2). As a result, the higher ash content in the wheat straw that was treated at $300{ }^{\circ} \mathrm{C}$ was responsible for its lower calorific values vs. that of the peat that was torrefied at the same temperature, although the HHV on the organic ash free basis of torrefied wheat straw, in contrast, was higher, i.e., $30 \mathrm{MJ} / \mathrm{kg}$ vs. $27.4 \mathrm{MJ} / \mathrm{kg}$ for peat.

Elemental analysis of the tar fractions that were obtained by the torrefaction of wheat straw, softwood, and peat indicates lower $\mathrm{O} / \mathrm{C}$ and $\mathrm{H} / \mathrm{C}$ values and higher $\mathrm{HHV}$ in comparison with the HHV of the starting biomass (Table 2). According to the data that are presented in Table 2, the tar fractions can be considered as an ash free biofuel with calorific values that exceed by $10-16 \%$ that of the starting material. The practical absence of ash in the tar fractions, in contrast to the case of the starting and torrefied biomass, can be considered as a significant advantage of the tar fractions in terms of their possible application for heat energy production.

Non-isothermal TG/DTG/DSC tests were performed in the air atmosphere to study the combustion of both the main-stream and side-stream products of MW torrefaction, e.g., solid and tar fractions. Exemplified by the products that were obtained at $300{ }^{\circ} \mathrm{C}$, the contrast behavior of solid and tar fractions that were derived from different types of biomass at the same conditions of thermal analysis is demonstrated (Figure 8).

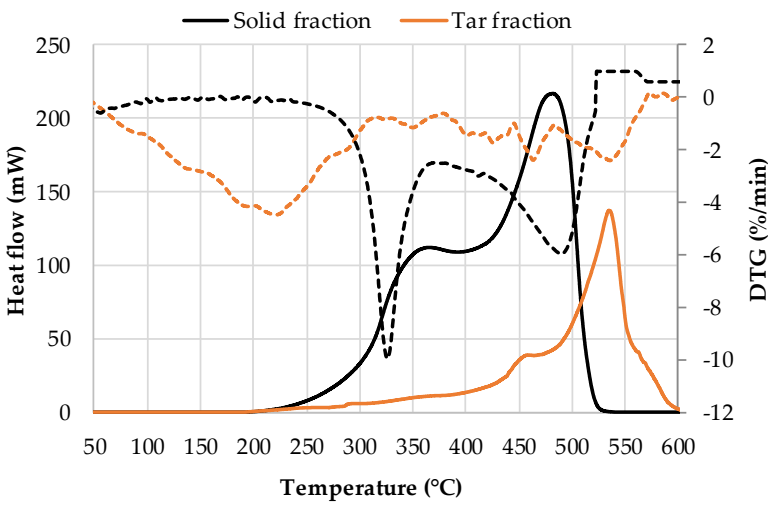

(a)

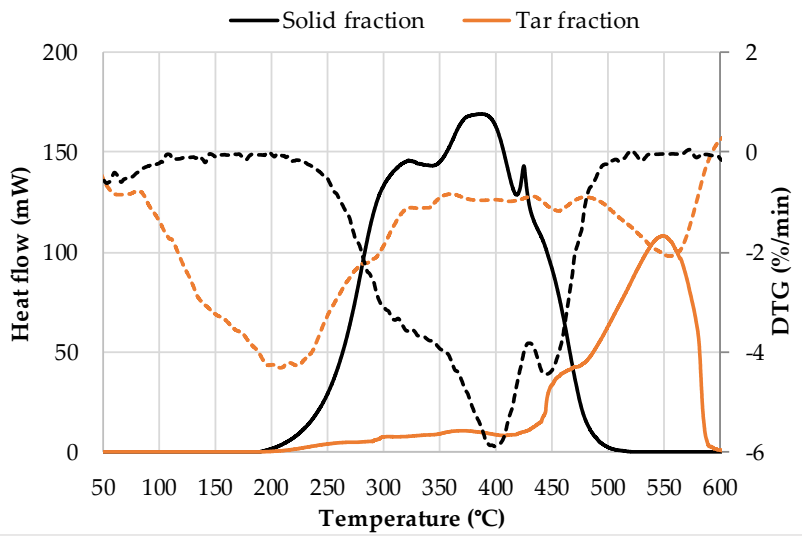

(b)

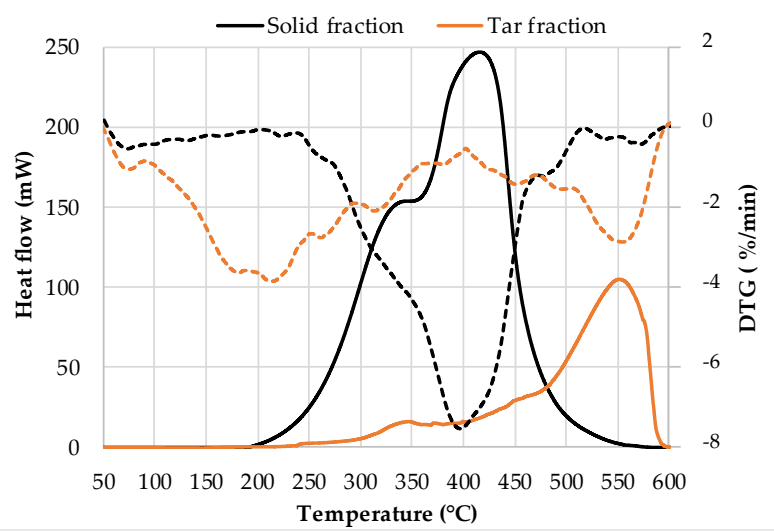

(c)

Figure 8. DTG (dashed line) and DSC (unbroken line) curves of the solid and tar fractions that were obtained from different types of biomass by MW-assisted torrefaction at $300^{\circ} \mathrm{C}$ : (a) softwood, (b) wheat straw, and (c) peat. 
As was shown, the exothermic process started at temperatures of about $225^{\circ} \mathrm{C}$ for both the solid and tar fractions (Figure 8). However, for the solid fractions, only a small amount of biomass (2-3\%) was removed without producing heat.

In contrast to the solid fractions, about 30-35\% of the tar fractions was removed without heat production. Obviously, this can be explained by the partial evaporation of high volatile products, predominantly of carbohydrate origination, which was determined by GC, including alcohols, ester, aliphatic aldehyde, ketones, as well as furan and pyran derivatives. The magnitude of the evaporation temperature was not sufficient for their thermal oxidation. Moreover, it was shown that the carboxylic acids that were present in the bio-oil that was derived from solid biomass by pyrolysis do not directly react with other components to form polymeric products but they act as a catalyst for condensation reactions via the electrophilic substitution and aldol condensation mechanism between other components at an elevated temperature [31]. Low molecular phenolic compounds in these conditions directly react with other products due to the presence of conjugated $\pi$ bonds, with the formation of high molecular products; among sugar derivatives, furan and furfural derivatives have the highest activity towards polymerization for the same reason. The reaction of phenolic compounds with each other and with furfural, with the formation of phenolic resin, is one of the pathways of phenolic low molecular biooil components' conversion at thermal treatment [26]. We can assume that the partial condensation/polymerization of low molecular components of tar take place as a result of its heating. The DSC tests that were performed in the temperature range of $20-650{ }^{\circ} \mathrm{C}$ in nitrogen media, avoiding the oxidation reaction of tar samples that were obtained at $300{ }^{\circ} \mathrm{C}$, testified the exothermic reactions started at $\mathrm{T} \geq 100{ }^{\circ} \mathrm{C}$, with the summary heat effect of $1.6 \pm 0.3 \mathrm{~kJ} / \mathrm{g}$. The fixed carbon content that was defined as the residual sample weight at $650{ }^{\circ} \mathrm{C}$ for softwood-, wheat straw-, and peat-derived tars was $13.9 \%, 11.6 \%$, and $15.9 \%$, respectively. As was shown, in the temperature range of $300-400{ }^{\circ} \mathrm{C}$, the rate of mass loss decreased significantly, but the exothermic process appeared, which can be explained by condensation reactions, accompanied by the liberation of water (Figure 8). Besides, in this region, the partial thermal oxidation of more complex and, therefore, high volatile products such as levoglucosan and levoglucosenone with a boiling point of $381{ }^{\circ} \mathrm{C}$ and $231{ }^{\circ} \mathrm{C}$, respectively, as well as the long-chain hydrocarbons and fatty acids, could occur. Therefore, in the temperature range of $400-600{ }^{\circ} \mathrm{C}$, the thermal degradation of more complicated products that were obtained by the polymerization of low molecular components of tar, followed by the removed volatiles' oxidation, as well as the exothermic reaction of the heterogenic oxidation of the formed char, take place. Those processes are accompanied by an essential heat release.

The heat that was liberated as a result of the thermal oxidation/combustion of biomass in conditions of non-isothermal DSC in air media is based on the area under the DSC curve (Figure 9).

In the case of softwood and peat, the volatilization of the starting biomass and torrefied solid fractions, followed by the oxidation of light volatile matter, is responsible for the first exothermic reaction region in the temperature range of $200-350{ }^{\circ} \mathrm{C}$. It is recognized that the second region is responsible for the combustion of fixed carbon in biomass, which proceeds at a higher temperature, with the peak heat release at $400-475{ }^{\circ} \mathrm{C}$ [32]. A total of three peaks of the heat flow were observed on the DSC curves of the non-treated and torrefied wheat straw, testifying a more complicated process of combustion of wheat straw-derived solids. It can be proposed that two distinguished regions with peaks at $375{ }^{\circ} \mathrm{C}$ and $425{ }^{\circ} \mathrm{C}$ are responsible for the combustion of more and less amorphous char [33].

For all the samples under study, the heat that was liberated as a result of combustion of both volatiles and char increased with increasing torrefaction temperature. This testifies that both factors, i.e., increasing of the fixed carbon content in solids and higher calorific values of the volatiles that were formed at the first combustion step, are responsible for enhancing the liberated heat amount in the DSC tests of the torrefied solid fractions vs. the case of non-treated biomass. 


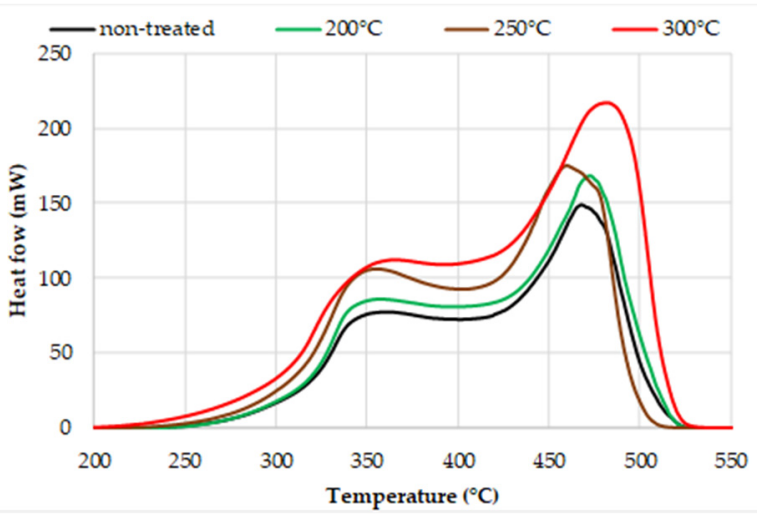

(a)

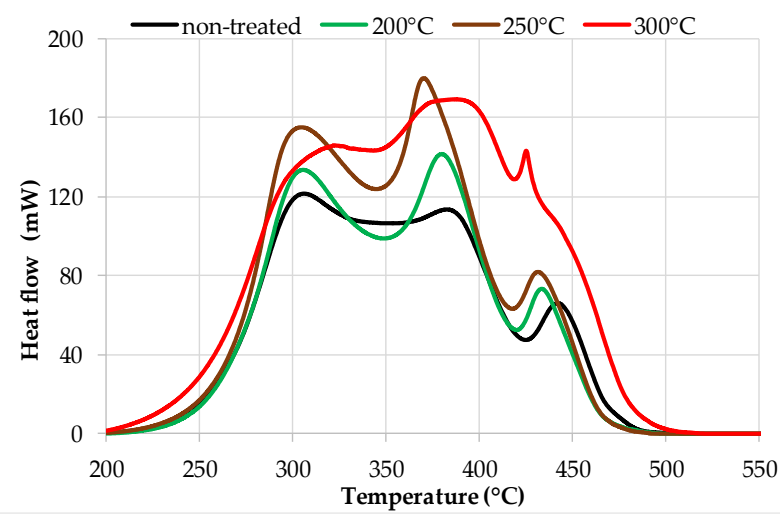

(b)

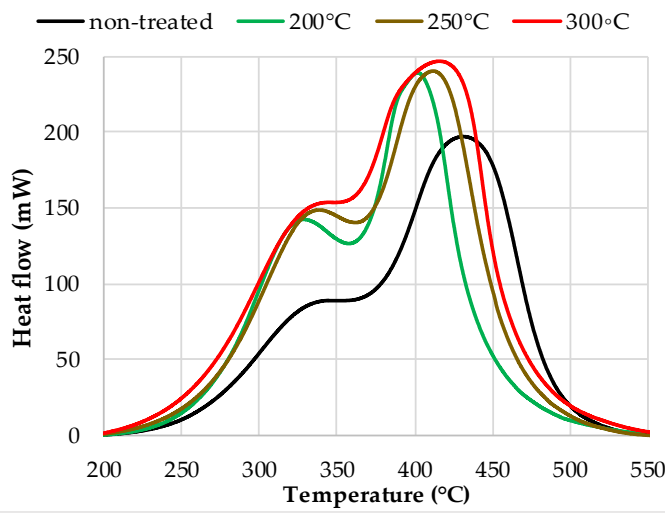

(c)

Figure 9. DSC curves of the non-treated biomass and the solid fractions that were obtained by its MW-assisted torrefaction at different temperature: (a) softwood, (b) wheat straw, and (c) peat.

Similar combustion profiles for all the tar fractions that were obtained from different biomass samples by MW processing at $200-300{ }^{\circ} \mathrm{C}$ were observed (Figure 10). The dominant $(\leq 90 \%)$ portion of heat energy was liberated in the temperature range of $400-650{ }^{\circ} \mathrm{C}$ that corresponded to the combustion of $27-28 \%, 24-40 \%$, and $30-35 \%$ of the biomass in terms of the starting weight of softwood-, wheat straw-, and peat-derived tar samples, respectively. Besides, the peak of the heat release on the DSC curves of the tar fractions is shifted into the region of higher temperature by $100-150{ }^{\circ} \mathrm{C}$ in comparison with that which was observed for the solid fractions (Figure 8). This can be explained by the fact that the active condensation/polymerization reactions take place between the tar components as a result of their second heating, followed by the formation of char with, probably, a less amorphous structure, and a lower content of non-carbon admixtures in it, which needs a comparatively high energy input for its oxidation. The total amount of the heat that is liberated by the combustion of the starting biomass and the main- and side-stream products of its torrefaction is presented in Table 3. The heat input of the fractions, expressed in percent of their HHV, was defined as the efficiency of thermal oxidation in conditions of thermal analysis, modelling the real combustion processing.

It was shown by the DSC tests that the heat that was liberated by the combustion of the solid fractions that were obtained by the MW-assisted torrefaction of softwood and wheat straw that was performed at $250{ }^{\circ} \mathrm{C}$ and $300{ }^{\circ} \mathrm{C}$ enhanced the heat output for the non-treated biomass by $20 \%$ and $60 \%$, respectively (Table 3 ). For the peat samples, this increment was in the range of $25-37 \%$ that can be explained by a significantly higher heat output for the non-treated peat vs. that of the non-treated softwood and wheat straw. Taking into account the standard deviation values, it can be concluded that the MW torrefaction that was performed at $200{ }^{\circ} \mathrm{C}$ does not practically increase the liberated heat amount for the 
solid fractions in comparison with that of the oven dried non-treated softwood and wheat straw samples. In the case of peat biomass, the increment of heat output was more visible. However, in real combustion processes, these advantages will appear more clearly due to the lower content of water $(\sim 2-3 \%)$ in pellets that were torrefied at $200{ }^{\circ} \mathrm{C}$ vs. the water content $(12-15 \%)$ in the non-treated pellets. The efficiency coefficients that are presented in Table 3 testify that, at combustion of all solid samples that were torrefied at $250{ }^{\circ} \mathrm{C}$ and $300{ }^{\circ} \mathrm{C}$, their energetic potential is utilized more completely in comparison with the case of the non-treated biomass.

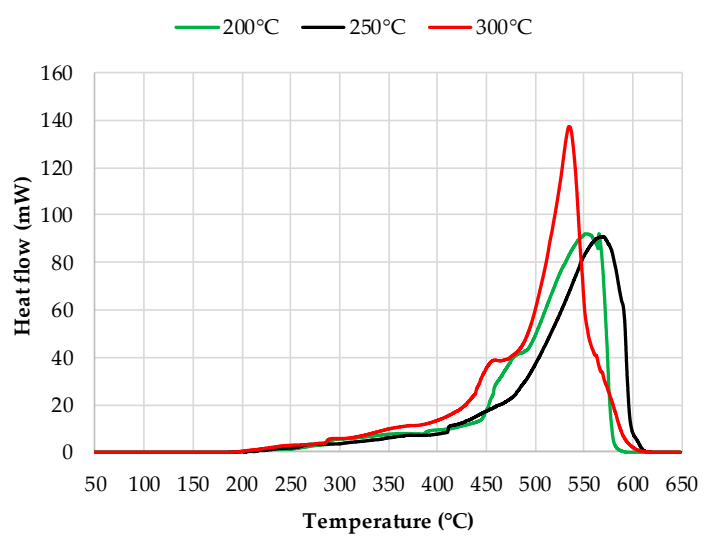

(a)

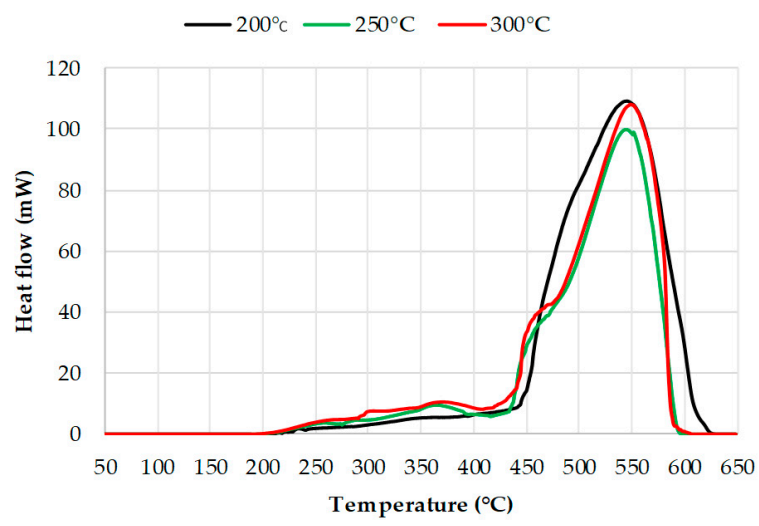

(b)

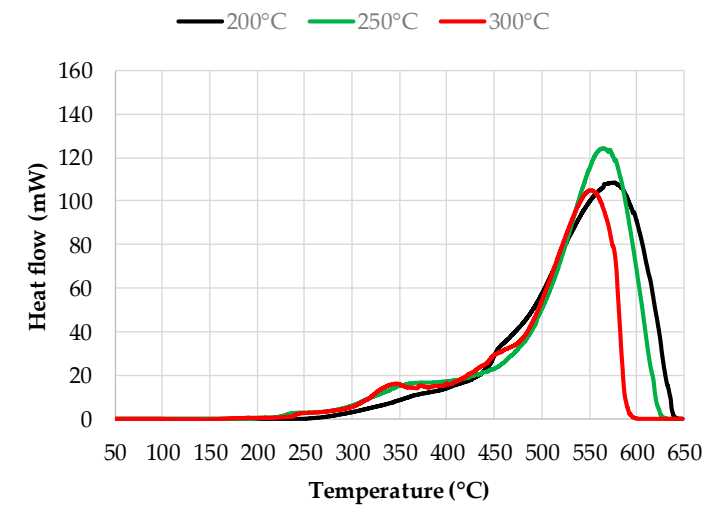

(c)

Figure 10. DSC curves of tar fractions that were obtained by MW-assisted torrefaction of biomass at different temperature: (a) softwood, (b) wheat straw, and (c) peat.

According to DSC tests of tar fractions, the heat that was liberated by their combustion was much lower in comparison with the corresponding data for the non-treated biomass and torrefied solid fractions due to the low process efficiency. It is proposed that the regimes of the DSC tests, chosen for modelling the combustion process, including the continuous heating of a sample with a constant rate of $10{ }^{\circ} \mathrm{C} / \mathrm{min}$, were not favorable for the tar samples, the thermal conversion of which was rather a complicated process due to a lower stability, especially at thermal treatment [34].

As was mentioned above, at least three different processes can be performed in tar fractions at DSC testing, including (1) evaporation of high volatile products without their oxidation, (2) condensation reactions with participation of phenolic compounds with liberation of water, and (3) volatilization of the formed resin-like compounds and char formation, followed by their oxidation. Spraying of tar into the high temperature combustion chamber can be assumed to be favorable for more complete combustion of tar fractions, accompanied by the liberation of heat energy in an amount coinciding with 
their calorific values. Hence, the co-combustion of MW-assisted torrefaction of tars that were obtained from softwood, wheat straw, and peat biomass with heavy fuel oil could be possible pathways for their energetic valorization.

Table 3. Heat output (Q) and the calculated efficiency (Eff.) coefficients according to the DSC tests in air media of the solid and tar fractions that were obtained by MW-assisted torrefaction of biomass at different temperatures.

\begin{tabular}{|c|c|c|c|c|}
\hline \multirow[t]{3}{*}{ MW Treatment, ${ }^{\circ} \mathrm{C}$} & \multicolumn{4}{|c|}{ Softwood } \\
\hline & \multicolumn{2}{|c|}{ Solid Fraction } & \multicolumn{2}{|c|}{ Tar Fraction } \\
\hline & $Q(k J / g)$ & Eff., \% & $Q(k J / g)$ & Eff., \% \\
\hline n.t & $10.1 \pm 0.5$ & 50.7 & - & - \\
\hline 200 & $10.2 \pm 0.6$ & 50.5 & $5.5 \pm 0.3$ & 26.6 \\
\hline 250 & $12.5 \pm 0.7$ & 58.1 & $5.6 \pm 0.2$ & 26.7 \\
\hline \multirow[t]{4}{*}{300} & $16.6 \pm 0.8$ & 67.8 & $6.4 \pm 0.4$ & 29.5 \\
\hline & \multicolumn{4}{|c|}{ Wheat straw } \\
\hline & \multicolumn{2}{|c|}{ Solid fraction } & \multicolumn{2}{|c|}{ Tar fraction } \\
\hline & $\mathrm{Q}(\mathbf{k J} / \mathrm{g})$ & Eff., \% & $Q(\mathbf{k J} / \mathrm{g})$ & Eff., \% \\
\hline n.t & $10.8 \pm 0.5$ & 58.7 & - & - \\
\hline 200 & $11.0 \pm 0.6$ & 58.7 & $7.6 \pm 0.5$ & 32.6 \\
\hline 250 & $13.0 \pm 0.8$ & 66.3 & $6.2 \pm 0.3$ & 28.8 \\
\hline \multirow[t]{4}{*}{300} & $17.7 \pm 1.0$ & 68.0 & $6.6 \pm 0.3$ & 20.7 \\
\hline & \multicolumn{4}{|c|}{ Peat } \\
\hline & \multicolumn{2}{|c|}{ Solid fraction } & \multicolumn{2}{|c|}{ Tar fraction } \\
\hline & $Q(\mathbf{k J} / \mathrm{g})$ & Eff., \% & $Q(\mathbf{k J} / \mathrm{g})$ & Eff., \% \\
\hline n.t & $14.8 \pm 0.7$ & 70.8 & - & - \\
\hline 200 & $15.9 \pm 0.8$ & 72.3 & $9.0 \pm 0.5$ & 42.0 \\
\hline 250 & $18.5 \pm 1.0$ & 72.8 & $6.5 \pm 0.5$ & 29.8 \\
\hline 300 & $20.4 \pm 1.2$ & 75.8 & $6.9 \pm 0.5$ & 29.0 \\
\hline
\end{tabular}

\section{Discussion}

Main- and side-stream products, mainly solid and condensable products of microwaveassisted torrefaction of commercial softwood, wheat straw, and peat pellets, performed at $200{ }^{\circ} \mathrm{C}, 250{ }^{\circ} \mathrm{C}$, and $300{ }^{\circ} \mathrm{C}$, respectively, were separated. The condensable products were distillated to separate the tar and water-enriched fractions. It was shown that, alongside with water, the distillated fractions contained a wide range of organic compounds, the content of which was increased with increasing torrefaction temperature. Organic acids, with the domination of the acetic acid portion, were the main components of the distillates of wood- and wheat straw-derived condensates, with the total organic content of up to $90 \%$ in them. The concentration of all the organic acids recalculated on acetic acids in the distillates of softwood- and wheat straw-derived condensates varied in the range of 10-25 g/L and 25-79 g/L, respectively. The distillates of the peat-derived condensates contained furfural and 5-methyl furfural as the dominant organic components, followed by organic acids, with total organic contents of $56-65 \%$ and $30-35 \%$ in them, respectively. Because the distillates do not have any energetic valuable effect, their purification or/and target utilization of the organics that are contained in them will be necessary to eliminate the negative environmental impact. The solid and tar fractions were evaluated in terms of their chemical and elemental composition, and the thermal oxidative characteristics, with focus on their application as biofuel. The results that were obtained testified the simultaneous development of destruction and condensation processes in lignocarbohydrate complexes during microwave treatment that finally leads to the increase of the relative portion of condensed aromatic compounds in solid fractions, increasing their HHV. In contrast to the softwood and wheat straw, an increase in the content of both the aromatic and oxygen free lipophilic compounds in torrefied peat was established, resulting in their highest HHV among all the samples under study. The DSC tests have confirmed a $20-60 \%$ increase in the 
heat amount that was liberated as a result of the combustion of the solid fractions that were obtained by the MW-assisted torrefaction of different types of biomass at $250{ }^{\circ} \mathrm{C}$ and $300{ }^{\circ} \mathrm{C}$ in comparison with the case of the non-treated samples. Moreover, the enhanced values of the efficiency coefficients indicate that the energetic potential of the torrefied biomass was utilized more completely in comparison with the case of the non-treated biomass.

In all cases, the HHV values of the separated tar fractions exceed those of the nontreated biomass and varied in the range of $20.7-23.9 \mathrm{MJ} / \mathrm{kg}$ that allowed to characterize them as a potentially valuable low-ash biofuel. It was established that the behavior of tar fractions at thermal conversion differed significantly vs. that of the solid fractions. Only $\leq 42 \%$ of the heat energy that was potentially contained in these fractions was detected by the DSC tests that were performed in air vs. the $59-76 \%$ that were determined for the solid fractions in the same testing conditions.

This can be explained by the complicated process of tar transformation in conditions of the non-isothermal DSC tests that were performed, including the evaporation of low molecular and high volatile products of carbohydrate thermal degradation without exothermic oxidation, as well as condensation/polymerization reactions between the components of tars at heating. It can be assumed that co-combustion with heavy fuel oil could be a possible pathway for the energetic valorization of the tar fractions that were obtained by MW-assisted torrefaction of softwood, wheat straw, and peat biomass pellets. Besides, based on the obtained results, the future testing of tars as antimicrobial compositions and as a raw material for obtaining low-ash biochar will be quite urgent in terms of the valorization of side-stream products of MW-assisted torrefaction of lignocellulosic biomass beyond energy use.

The results of the performed experiments testified that the MW-assisted torrefaction of pelletized biomass can be a well controllable, low energy expensive, and a fast process, which has the prospect of practical application. The ability of upscaling the microwave device is a necessary circumstance for the implementation of this perspective. Thus, the application of a metal rotated reactor-resonator of greater volume instead of a brittle Si glass reactor that is placed inside the metal resonator and increasing of the MW power will be necessary. In the new installation, the product will be located directly in a metal resonator, with the introduction of microwave energy through radio transparent windows. The design of such a construction consisted of a reactor-resonator with a volume of $0.1 \mathrm{~m}^{3}$, that was equipped with magnetrons with a capacity of $9 \mathrm{~kW}$ and a loading weight of $6 \mathrm{~kg}$ pellets, is developed by the authors in the framework of the existing European Project.

Author Contributions: Conceptualization, A.A. and M.Z.; Data curation, M.P. and J.P.; Formal analysis, J.P. and A.A.; Funding acquisition, M.Z.; Investigation, L.J., M.P. and Y.A.; Methodology, J.P., M.Z. and A.A.; Project administration, M.Z.; Resources, Y.A. and M.Z.; Supervision, A.A. and M.Z.; Visualization, A.A. and L.J.; Writing—original draft, A.A., Writing—review \& editing, A.A., M.Z., M.P. and J.P. All authors have read and agreed to the published version of the manuscript.

Funding: This research was funded by the European Regional Development Fund and Grant Nr. 1.1.1.1/19/A/010.

Institutional Review Board Statement: Not applicable.

Informed Consent Statement: Not applicable.

Data Availability Statement: The data presented in this study are available on request from the corresponding author.

Conflicts of Interest: The authors declare no conflict of interest. 


\section{References}

1. European Commission. Communication from the Commission to the European Parliament, the Council, the European Economic and Social Committee and the Committee of the Regions, Stepping Up Europe's 2030 Climate Ambition, Investing in a Climate-Neutral Future for the Benefit of Our People; European Commission: Brussels, Belgium, 2020. Available online: https://eur-lex.europa.eu/legal-content/ EN/TXT/?uri=CELEX\%3A52020DC0562 (accessed on 1 February 2022).

2. Calderon, C. Bioenergy Europe Statistical Report; Bioenergy Europe: Brussels, Belgium, 2019. Available online: https: // platformduurzamebiobrandstoffen.nl/infotheek/bioenergy-europe-statistical-report-2019/ (accessed on 1 February 2022).

3. Jakob, M.; Steckel, J.C.; Jotzo, F.; Sovacool, B.K.; Cornelsen, L.; Chandra, R.; Edenhofer, O.; Holden, C.; Löschel, A.; Nace, T.; et al. The future of coal in a carbon-constrained climate. Nat. Clim. Chang. 2020, 10, 704-707. [CrossRef]

4. Centre for Research on Energy and Clean Air. Powering Down Coal-COP26's Impact on the Global Coal Power. 2020, Volume 590 Available online: https:/ / energyandcleanair.org/wp/wp-content/uploads/2021/11/Glasgow-impact-on-coal.pdf (accessed on 1 February 2022).

5. Lang, A.; Bradley, D.; Gauthier, G. Global Bioenergy Statistics, World Bioenergy Association. 2016. Available online: http://www. worldbioenergy.org/uploads/201210\%20WBA\%20GBS\%202020.pdf (accessed on 1 February 2022).

6. USDA. USDA Biofuel Annual 2020. In Gain Report; USDA Report E42020-003; USDA: Washington, DC, USA, 2020. Available online: https: / / apps.fas.usda.gov/newgainapi/api/Report/DownloadReportByFileName?fileName=Biofuels $\% 20$ Annual_The $\%$ 20Hague_European\%20Union_06-29-2020 (accessed on 1 February 2022).

7. Nunes, L.J.R.; Matias, J.C.O. Biomass Torrefaction as a Key Driver for the Sustainable Development and Decarbonization of Energy Production. Sustainability 2020, 12, 922. [CrossRef]

8. Chen, W.-H.; Lin, B.-J.; Lin, Y.-Y.; Chu, Y.-S.; Ubando, A.T.; Show, P.L.; Ong, H.C.; Chang, J.-S.; Ho, S.-H.; Culaba, A.B.; et al. Progress in biomass torrefaction: Principles, applications and challenges. Prog. Energy Combust. Sci. 2021, 82, 100887. [CrossRef]

9. Batidzirai, B.; Mignot, A.P.R.; Schakel, W.B.; Junginger, H.M.; Faaij, A.P.C. Biomass torrefaction technology: Techno-economic status and future prospects. Energy 2013, 62, 196-214. [CrossRef]

10. Agar, D.; Wihersaari, M. Bio-coal, torrefied lignocellulosic resources-Key properties for its use in co-firing with fossil coal-Their status. Biomass Bioenergy 2012, 44, 107-111. [CrossRef]

11. Jindo, K.; Mizumoto, H.; Sawada, Y.; Sanchez-Monedero, M.A.; Sonoki, T. Physical and chemical characterization of biochars derived from different agricultural residues. Biogeosciences 2014, 11, 6613-6621. [CrossRef]

12. Thrän, D.; Witt, J.; Schaubach, K.; Kiel, J.; Carbo, M.; Maier, J.; Ndibe, C.; Koppejan, J.; Alakangas, E.; Majer, S.; et al. Moving torrefaction towards market introduction: Technical improvements and economic-environmental assessment along the overall torrefaction supply chain through the SECTOR project. Biomass Bioenergy 2016, 89, 184-200. [CrossRef]

13. Strauss, W. "Black pellets" - A financial analysis of costs and benefits: Can they provide cheaper energy than white pellets? In Globally Respected Consultants in the Wood Pellet Sector; FutureMetrics LLC: New York, NY, USA, 2014; pp. 1-11.

14. Arpia, A.A.; Chen, W.-H.; Ubando, A.T.; Tabatabaei, M.; Lam, S.S.; Culaba, A.B.; De Luna, M.D.G. Catalytic microwave-assisted torrefaction of sugarcane bagasse with calcium oxide optimized via Taguchi approach: Product characterization and energy analysis. Fuel 2021, 305, 121543. [CrossRef]

15. Arshanitsa, A.; Akishin, Y.; Zile, E.; Dizhbite, T.; Solodovnik, V.; Telysheva, G. Microwave treatment combined with conventional heating of plant biomass pellets in a rotated reactor as a high rate process for solid biofuel manufacture. Renew. Energy 2016, 91, 386-396. [CrossRef]

16. Ethaib, S.; Omar, R.; Kamal, S.M.M.; Awang Biak, D.R.; Zubaidi, S.L. Microwave-Assisted Pyrolysis of Biomass Waste: A Mini Review. Processes 2020, 8, 1190. [CrossRef]

17. Yek, P.N.Y.; Osman, M.S.; Wong, C.C.; Wong, C.S.; Kong, S.H.; Sie, T.S.; Foong, S.Y.; Lam, S.S.; Liew, R.K. Microwave wet torrefaction: A catalytic process to convert waste palm shell into porous biochar. Mater. Sci. Energy Technol. 2020, 3, $742-747$. [CrossRef]

18. Mitani, T. Recent Progress on Microwave Processing of Biomass for Bioenergy Production. J. Jpn. Pet. Inst. 2018, 61, 113-120. [CrossRef]

19. Priecel, P.; Lopez-Sanchez, J.A. Advantages and Limitations of Microwave Reactors: From Chemical Synthesis to the Catalytic Valorization of Biobased Chemicals. ACS Sustain. Chem. Eng. 2019, 7, 3-21. [CrossRef]

20. Guo, W.; Lim, C.J.; Bi, X.; Sokhansanj, S.; Melin, S. Determination of effective thermal conductivity and specific heat capacity of wood pellets. Fuel 2013, 103, 347-355. [CrossRef]

21. Fernandez, Y.; Arenillas, A.; Angel, J. Microwave Heating Applied to Pyrolysis. In Advances in Induction and Microwave Heating of Mineral and Organic Materials; Arenillas, A., Ed.; InTech: Rijeka, Croatia, 2011; Chapter 31.

22. Barskov, S.; Zappi, M.; Buchireddy, P.; Dufreche, S.; Guillory, J.; Gang, D.; Hernandez, R.; Bajpai, R.; Baudier, J.; Cooper, R.; et al. Torrefaction of biomass: A review of production methods for biocoal from cultured and waste lignocellulosic feedstocks. Renew. Energy 2019, 142, 624-642. [CrossRef]

23. Garrote, G.; Domínguez, H.; Parajó, J.C. Study on the deacetylation of hemicelluloses during the hydrothermal processing of Eucalyptus wood. Eur. J. Wood Prod. 2001, 59, 53-59. [CrossRef]

24. Pawar, P.M.A.; Koutaniemi, S.; Tenkanen, M.; Mellerowicz, E.J. Acetylation of woody lignocellulose: Significance and regulation. Front. Plant Sci. 2013, 4, 118. [CrossRef] 
25. Sutton, R.; Sposito, G. Molecular Structure in Soil Humic Substances: The New View. Environ. Sci. Technol. 2005, 39, 9009-9015. [CrossRef] [PubMed]

26. Chi, C.; Zhang, Z.; Chang, H.; Jameel, H. Determination of Furfural and Hydroxymethylfurfural Formed From Biomass Under Acidic Conditions. J. Wood Chem. Technol. 2009, 29, 265-276. [CrossRef]

27. Hänninen, K. Historical and current progress in understanding the origin and structure of humic substances. Chem. Ecol. 2010, 26, 1-11. [CrossRef]

28. Chio, C.; Sain, M.; Qin, W. Lignin utilization: A review of lignin depolymerization from various aspects. Renew. Sustain. Energy Rev. 2019, 107, 232-249. [CrossRef]

29. Walsh, D.J.; Livinghouse, T.; Goeres, D.M.; Mettler, M.; Stewart, P.S. Antimicrobial Activity of Naturally Occurring Phenols and Derivatives Against Biofilm and Planktonic Bacteria. Front. Chem. 2019, 7, 653. [CrossRef] [PubMed]

30. Hossain, M.M.; Scott, I.M.; McGarvey, B.D.; Conn, K.; Ferrante, L.; Berruti, F.; Briens, C. Insecticidal and anti-microbial activity of bio-oil derived from fast pyrolysis of lignin, cellulose, and hemicellulose. J. Pest Sci. 2014, 88, 171-179. [CrossRef]

31. Hu, X.; Wang, Y.; Mourant, D.; Gunawan, R.; Lievens, C.; Chaiwat, W.; Gholizadeh, M.; Wu, L.; Li, X.; Li, C.-Z. Polymerization on heating up of bio-oil: A model compound study. AIChE J. 2013, 59, 888-900. [CrossRef]

32. Kok, M.V.; Özgür, E. Thermal analysis and kinetics of biomass samples. Fuel Process. Technol. 2013, 106, 739-743. [CrossRef]

33. Tomczyk, A.; Sokołowska, Z.; Boguta, P. Biochar physicochemical properties: Pyrolysis temperature and feedstock kind effects. Rev. Environ. Sci. Bio/Technol. 2020, 19, 191-215. [CrossRef]

34. Venderbosch, R.H.; Ardiyanti, A.R.; Wildschut, J.; Oasmaa, A.; Heeres, H.J. Stabilization of biomass-derived pyrolysis oils. J. Chem. Technol. Biotechnol. 2010, 85, 674-686. [CrossRef] 